\title{
Psikoedukasi Pendidikan Seks untuk Meningkatkan Sikap Orangtua dalam Pemberian Pendidikan Seks
}

\author{
Isnatul Chasanah ${ }^{1}$ \\ Fakultas Psikologi, \\ Universitas Muhammadiyah Malang
}

\begin{abstract}
: 8-10 years old are the end period of children where children start to think logically, critically, creatively, and scientifically. Along with so much cases on child sexual violence, sex education is important to understand self, environment, and people around. Sex education is an effort to educate and direct proper sexual behavior in children. In Indonesia, sex education for children is still considered as taboo, especially at the age of early and middle age of children. Parents assume that sex education is inappropriate for young children. Psychoeducation needed to improve attitudes of parents in providing sex education on children. Subject of research are parents in grade III of SD Negeri M Malang ( $N=19)$. This research is pre-experiments research with one group pretest posttest design. The results showed an increase in parents attitudes before and after intervention ( $t$ $=-2,932 ; p=0.009)$. Thus, it can be concluded that the psychoeducation effective to improve the attitude of the parents in giving sex education on children
\end{abstract}

Keywords: psychoeducation, sex education, 8-10 years children

\begin{abstract}
ABSTRAK: Masa anak usia 8-10 tahun adalah masa anak-anak akhir yang mulai dapat bernalar secara logis, berpikir kritis, kreatif, dan ilmiah. Seiring maraknya kasus kekerasan seksual anak, pendidikan seks penting diberikan sebagai bekal untuk memahami diri, lingkungan sekitar, dan orang-orang dalam pergaulannya. Pendidikan seks adalah upaya mendidik dan mengarahkan perilaku seksual secara baik dan benar pada anak. Di Indonesia, pendidikan seks untuk anak masih dianggap tabu, terutama pada usia anak-anak awal dan tengah. Orangtua menganggap pendidikan seks belum pantas diberikan pada anak kecil. Maka, psikoedukasi perlu dilakukan untuk meningkatkan sikap orang tua dalam memberikan pendidikan seks pada anak. Subjek penelitian adalah orang tua kelas III di SDN M Malang yang dipilih meggunakan teknik pengambilan sampel yaitu populasi. Penelitian ini adalah penelitian pre-eksperimen dengan desain one group pretest posttest. Hasil penelitian menunjukkan adanya peningkatan sikap orang tua sebelum dan sesudah pemberian psikoedukasi $(t=-2.932 ; p=0.009)$. Dengan demikian, dapat disimpulkan bahwa psikoedukasi dapat digunakan untuk meningkatkan sikap orang tua dalam pemberian pendidikan seks pada anak.
\end{abstract}

Kata kunci: psikoedukasi, pendidikan seks, anak usia 8-10 tahun

\footnotetext{
${ }^{1}$ Korespondensi mengenai artikel ini dapat melalui: isnatulchasanah@yahoo.com
} 
Pendidikan seks penting diajarkan di era digital. Hal ini tak lepas dari banyaknya kasus kekerasan seksual (sex abuse) yang marak terjadi di Indonesia. Selain itu, pendidikan seks yang dilakukan sejak dini akan memberikan pengaruh pada kehidupan anak saat remaja. Semakin berkembangnya zaman, rasa ingin tahu dan penasaran anak semakin tinggi jika dibandingkan dengan anak zaman dahulu. Anak menjadi lebih kritis, baik dari segi sifat, sikap, maupun perilaku. Oleh karenanya, mewadahi rasa ingin tahu anak yang tinggi, peran orang tua menjadi vital dalam hal penyampaian pendidikan seks demi mencegah anak memuaskan rasa ingin tahu melalui pihak lain yang belum tentu kebenarannya.

Kasus-kasus kekerasan seksual menjadi viral di berbagai media beberapa tahun terakhir. Baik media cetak maupun elektronik, baik lokal maupun nasional, kasus kekerasan seksual terjadi dengan berbagai motif dan disebabkan oleh berbagai latar belakang. Para pelaku kekerasan seksual pun beragam, tak melulu oleh pria dewasa. Berikut merupakan beberapa contoh kasus kekerasan seksual pada anak yang dirangkum peneliti dari tahun 2014 hingga 2016.

Tabel 1. Kasus Kekerasan Seksual di Indonesia tahun 2014-2016

\begin{tabular}{llll}
\hline No & Tahun & \multicolumn{1}{c}{ Kasus } & Sumber \\
\hline 1 & 2014 & $\begin{array}{l}\text { Di Sukabumi, AS (24) melakukan pencabulan } \\
\text { pada 89 anak. }\end{array}$ & Kompas.com \\
\hline 2 & 2014 & $\begin{array}{l}\text { Emon, seorang pedofilia yang melakukan } \\
\text { pencabulan dan sodomi pada puluhan anak di } \\
\text { bawah umur }\end{array}$ & $\begin{array}{l}\text { SUAR, Laporan Komnas } \\
\text { HAM 2014 }\end{array}$ \\
\hline 3 & 2014 & $\begin{array}{l}\text { Polisi: Tiga Siswa JIS Jadi Korban Pelecehan } \\
\text { Seksual }\end{array}$ & Berita Republika \\
\hline 4 & 2015 & Siswa kelas III SD Perkosa Bocah 7 Tahun & Berita Tempo \\
\hline 5 & 2016 & Guru mencabuli siswa SD usia 12 tahun & $\begin{array}{l}\text { Koran Surya edisi } \\
\text { Selasa,15 November 2016 }\end{array}$ \\
\hline 6 & 2016 & $\begin{array}{l}\text { 8 siswa SMP dan SD Perkosa Siswi 13 Tahun } \\
\text { Berita poskotanews.com }\end{array}$ \\
\hline 7 & 2016 & $\begin{array}{l}\text { Yuyun, bocah SMP di Bengkulu diperkosa 14 } \\
\text { lelaki hingga tewas lalu dibuang ke jurang }\end{array}$ & $\begin{array}{l}\text { BBC Indonesia } \\
\text { (www.bbc.com/indonesia) }\end{array}$ \\
\hline 8 & 2016 & $\begin{array}{l}\text { Siswa kelas 5 SD dicabuli oleh pamannya } \\
\text { sendiri }\end{array}$ & Megapolitan Kompas \\
\hline
\end{tabular}

Sementara itu, di kota Malang menurut bank data Woman Crisis Centre (WCC) Dian Mutiara, pada 2016 tercatat 131 kasus kekerasan perempuan dan anak, dengan 13 kasus kekerasan seksual di antaranya. Sementara itu, terhitung sejak awal Januari 2017, sudah 17 kasus kekerasan seksual di kota Malang yang terjadi.
Hasil observasi yang dilakukan peneliti di sebuah SD Negeri di kota Malang menunjukkan para siswa laki-laki bermain dengan para siswa perempuan. Siswa juga mengobrol di sela pelajaran atau jam istirahat dan saling meminjam perlengkapan sekolah. Para siswa juga berebut buku, mainan, atau alat tulis. Saat berebut sesuatu, terdapat siswa laki-laki yang mendorong bahu teman perempuan. Sebaliknya, 
terkadang siswa perempuan mendorong atau memukul teman laki-laki. Saat pelajaran berlangsung dan guru meminta siswa untuk mengerjakan sebuah tugas, siswa laki-laki mengunjungi bangku perempuan untuk berdiskusi atau mengerjakan tugas bersama. Sebaliknya, ada juga siswa perempuan yang mendatangi bangku siswa laki-laki untuk mengerjakan tugas bersama.

Berdasarkan data Komisi Perlindungan Anak Indonesia (KPAI), tahun 2011-2013 terdapat 7.605 kasus kekerasan anak. Dari jumlah tersebut, 2.131 kasus $(30,1 \%)$ adalah kekerasan seksual. Tiga lingkungan yang menjadi lokus kekerasan pada anak adalah lingkungan keluarga, sekolah, dan masyarakat. $78.3 \%$ anak menjadi pelaku kekerasan seksual dan sebagian besar karena pernah menjadi korban kekerasan seksual sebelumnya, atau pernah melihat kekerasan seksual yang dilakukan pada anak lain, lalu menirunya.

Di Indonesia, pendidikan seks untuk anak selama ini masih dianggap tabu, terutama pada usia anak-anak awal dan tengah. Orangtua beranggapan bahwa pendidikan seks belum pantas diberikan pada anak kecil. Padahal, pendidikan seks dalam keluarga merupakan salah satu alternatif dalam membekali anak-anak informasi tentang seks, kesehatan, dan masalah-masalah reproduksi secara benar. Kemampuan, keterampilan, dan kemauan orang tua dalam memberikan pendidikan seks akan menentukan perasaan anak pada masa mendatang (Herjanti, 2015).

Anugraheni (2012) menyatakan bahwa sebagian besar orang tua kurang berperan dalam pemberian pendidikan seks meski orang tua memiliki pengetahuan mengenai pendidikan seks yang cukup. Menurut data Pusat Pelayanan Terpadu tahun 2011, hal ini salah satunya karena sebagian besar orangtua beranggapan bawah pendidikan seks sudah didapat anak dari sekolah. Hasil penelitian terhadap orang tua muslim yang berpandangan tradisional di desa Cibeuteung Muara, kecamatan Ciseeng, kabupaten Bogor menunjukkan bahwa orang tua selama ini belum pernah membicarakan seks kepada anak karena menganggap seks adalah sesuatu yang tabu dan tidak boleh dibicarakan secara terbuka (Erni, 2013). Padahal, pendidikan seks penting diberikan lebih awal karena karakteristik dasar manusia dibentuk pada masa anak-anak. Pendidikan yang salah dapat mempengaruhi perkembangan berbagai bentuk penyimpangan seksual pada masa-masa berikutnya. Pendidikan seks pada anak usia dini dinilai dapat meluruskan pemahaman dan perilaku seks anak-anak sehingga bisa lebih positif (Roqib, 2008). Riset yang dilakukan Zelnik dan Kim pada 1982 (Helmi \& Paramastri, 1998) menunjukkan bahwa apabila orang tua bersedia mendiskusikan seks dengan anaknya, maka ada kecenderungan anak menunda perilaku seksual premarital atau sebelum pernikahan.

Peneliti memandang perlu pemberian pendidikan seks orang tua pada anak karena pada kisaran usia 8-10 tahun, dalam Islam anak sedang memasuki usia tamyiz (Rifani, 2014). Usia tamyiz menjadi masa yang sangat penting untuk mempersiapkan dan membiasakan anak untuk menerima tugas-tugasnya sebagai hamba Allah SWT. Pada usia ini anak diajarkan untuk mulai mengetahui perbedaan antara laki-laki dan perempuan. Anak juga dapat mulai diberi pemahaman tentang masa pubertas beserta perubahan yang terjadi pada tubuh. Pemberian wawasan sejak dini ini akan memberi efek positif pada anak.

Selain itu, anak akan mulai mengalami perkembangan baik secara fisik, kognitif, maupun sosioemosi. Untuk itu, penting bagi orang tua yang memiliki anak usia 8-10 tahun untuk memiliki ilmu mengenai urgensi pemberian pendidikan seks pada anak. Hal ini berguna untuk 
memberikan pemahaman sebagai langkah preventif kekerasan seksual pada anak, baik sebagai pelaku maupun korban. Harapannya, psikoedukasi ini akan menambah wawasan dan membuka cakrawala orang tua untuk menanamkan pendidikan seks sejak dini di lingkungan keluarga, sehingga berimplikasi pada berkurangnya kasus kekerasan seksual anak.

Hasil penelitian Asra (2013) juga menyebutkan psikoedukasi terbukti efektif dalam meningkatkan sikap orang tua untuk memberikan pendidikan seks pada anak. Berdasar data kasus kekerasan seksual pada anak dan pentingnya pendidikan seksual anak sejak dini, peneliti memandang penting untuk melakukan psikoedukasi mengenai pendidikan seks pada orangtua siswa berumur 8-10 tahun. Pasalnya, usia 8-10 tahun merupakan usia peralihan anak dari masa anak-anak awal menuju masa anakanak tengah-akhir. Pada usia ini, anak akan segera memasuki masa pubertas.

Psikoedukasi efektif untuk meningkatkan sikap karena mencakup beberapa teori dan praktik. Termasuk, teori sistem ekologi, teori perilaku kognitif, teori belajar, dan model dukungan sosial. Oleh karena itu, psikoedukasi digunakan sebagai alat mengedukasi masyarakat mengenai pemberian pendidikan seks pada anak dan memberikan soft skill masyarakat untuk dapat memberikan pendidikan seks pada anak (Lukens \& William, 2014).

\section{Metode Penelitian}

\section{Subjek Penelitian}

Subjek dalam penelitian ini adalah orang tua dari siswa dengan rentang usia 8-
10 tahun. Untuk memudahkan penelitian, peneliti mengambil subjek dari orang tua kelas 3 sekolah dasar (SD). Peneliti tidak membatasi karakteristik subjek, baik jenis kelamin, usia, pendidikan, atau pekerjaan. Hasil skor uji pemahaman dan skala sikap juga tidak mempengaruhi subjek yang akan mendapatkan psikoedukasi. Jumlah subjek yang mendapatkan psikoedukasi tentang pendidikan seks sebanyak 19 orang, yang terdiri dari 1 laki-laki dan 18 perempuan yang merupakan orang tua dari siswa kelas III SD Negeri M Malang. Keseluruhan subjek ini yang kemudian dianalisis hasilnya oleh peneliti. Subjek dipilih menggunakan teknik pengambilan sampel yakni populasi. Teknik populasi yakni subjek yang ditetapkan menjadi partisipan merupakan keseluruhan orang yang memiliki karakteristik tertentu yang ditetapkan oleh peneliti untuk dipelajari dan ditarik kesimpulannya.

\section{Rancangan Penelitian}

Penelitian ini menggunakan pendekatan kuantitatif dengan desain penelitian pre-eksperimen. Disebut preeksperimen karena dilaksanakan tanpa melakukan pengendalian terhadap variabelvariabel yang berpengaruh. Dalam penelitian ini, yang diutamakan adalah perlakuan saja, tanpa ada kelompok murni (Latipun, 2002).

Desain penelitian yang digunakan yakni desain perlakuan ulang one group pretest and posttest. Menurut Sugiyono (2012), one group pretest posttest adalah suatu teknik untuk mengetahui efek sebelum dan sesudah pemberian perlakuan. Secara bagan, desain penelitian eksperimen one group pretest posttest digambarkan sebagai berikut: 


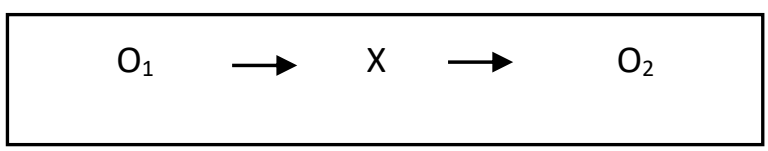

Gambar 1: one group pretest-posttes

$\mathrm{O}_{1} \quad$ : nilai prates (sebelum diberi perlakuan berupa psikoedukasi)

$\mathrm{X}$ : treatment (psikoedukasi)

$\mathrm{O}_{2}$ : nilai pascates (sesudah diberi perlakuan berupa psikoedukasi)

\section{Metode Pengumpulan Data}

Variabel penelitian menurut Sugiyono (2012) adalah suatu atribut atau sifat atau nilai dari orang, objek, atau kegiatan yang mempunyai variasi tertentu yang ditetapkan oleh peneliti untuk dipelajari dan ditarik kesimpulannya. Dalam penelitian ini, terdapat dua variabel, yakni variabel independen atau bebas (variabel $\mathrm{X}$ ) dan variabel dependen atau terikat (variabel Y). Adapun, variabel $\mathrm{X}$ dalam penelitian ini yaitu psikoedukasi tentang pendidikan seks, sedangkan variabel Y yaitu sikap orang tua terhadap pemberian pendidikan seks.

Psikoedukasi tentang pendidikan seks ialah suatu bentuk perlakuan yang dilakukan peneliti berupa pemaparan materi dan penayangan video edukatif tentang fenomena kekerasan seksual anak yang marak terjadi, tahapan perkembangan anak pada jenjang usia 8-10 tahun, pentingnya pendidikan seks yang diberikan pada anak, serta bagaimana peran yang mesti dilakukan orang tua dalam tiap tahap perkembangan anak sebagai bentuk pendidikan seks pada anak. Sebelum dan sesudah pelaksanaan psikoedukasi, peneliti terlebih dahulu memberikan prates dan pascates untuk mengukur sikap orang tua terhadap pemberian pendidikan seks yang nantinya akan dianalisis.

Sikap dalam penelitian ini adalah tingkatan afeksi baik yang bersifat positif maupun negatif dalam hubungannya dengan objek-objek psikologis. Peningkatan sikap orang tua terhadap pemberian pendidikan seks pada anak dimaksudkan sebagai suatu hasil meningkatnya kesadaran dan sikap orang tua untuk mengajarkan pendidikan seks sejak dini pada anak.

Instrumen penelitian berupa skala sikap dibuat oleh peneliti. Selain kuoesioner untuk prates dan pascates, peneliti menggunakan skala sikap untuk mengukur seberapa tinggi sikap, persepsi, dan pendapat orang tua terkait pemberian pendidikan seks pada anak. Skala sikap dibuat berdasarkan 3 aspek sikap, yakni kognitif (9 item), afektif ( 3 item), dan konatif (13 item). Sehingga, jumlah keseluruhan ada 50. Subjek diminta untuk memberi tanda centang pada kotak yang paling sesuai dengan keadaan mereka. Pernyataan dalam skala berisi sikap orang tua terhadap pendidikan seks. Skala sikap ini diujicobakan pada 57 responden yang merupakan orang tua dari siswa kelas 1 - 6 di SD Negeri L, Malang. Hasilnya, dari 45 item skala yang dibuat oleh peneliti, 25 item skala sikap terbukti valid dan reliabel.

\section{Prosedur Intervensi}

Psikoedukasi diartikan sebagai suatu intervensi yang dapat dilakukan pada individu, keluarga, dan kelompok yang fokus untuk mendidik pesertanya mengenai tantangan signifikan dalam hidup, membantu partisipan mengembangkan sumber-sumber dukungan dan dukungan sosial dalam menghadapi tantangan dan mengembangkan keterampilan coping (Walsh, 2010 dikutip dari Raudhoh, 2013). 
Peneliti menyusun modul yang dilakukan dengan mempelajari dan mendalami teoriteori tentang perkembangan anak dan teori sikap yang akan diberikan pada subjek yang akan diberi psikoedukasi. Setelah membuat modul, peneliti melakukan ujicoba pada orang tua siswa usia 8-10 tahun yang dipilih secara acak dan merupakan subjek yang berbeda dengan subjek psikoedukasi.

$$
\text { Ujicoba dilakukan dengan }
$$

memberikan modul tersebut dan meminta subjek ujicoba untuk memberi penilaian pada lembar evaluasi yang diberikan oleh peneliti. Poin-poin yang dinilai oleh subjek meliputi pemilihan tema edukasi, waktu pelaksanaan, suasana pelaksanaan, ice breaking, tayangan video, materi, sikap peneliti saat menyampaikan materi, dan nilai keseluruhan dari psikoedukasi tersebut. Indikator penilaian didasarkan pada beberapa kategori, yakni angka 1 (buruk), angka 2 (kurang), angka 3 (cukup), angka 4 (baik) dan angka 5 (memuaskan). Hasil ujicoba, subjek menyatakan memuaskan $8 \%$ (6 orang), bagus $75 \%$ (54 orang), cukup $17 \%$ (12 orang), dan sisanya kategori kurang dan buruk masing-masing $0 \%$.

Pada psikoedukasi ini, peneliti berperan sebagai fasilitator (narasumber) yang menguraikan materi mengenai pentingnya pendidikan seks pada anak dan apa saja hal-hal yang perlu diberikan dalam pendidikan seks pada anak. Pemberian psikoedukasi ini terbagi dalam 4 sesi. Sesi pertama, peneliti terlebih dahulu membuka kegiatan dan menyampaikan ucapan terima kasih atas kehadiran subjek pada kegiatan psikoedukasi, memperkenalkan diri, untuk menghangatkan suasana dan mendekatkan emosi subjek, peneliti memberikan ice breaking berupa senam otak melalui video yang ditampilkan dan diikuti oleh subjek. Selepas senam otak, peneliti memberikan pretest berupa kuesioner dan skala sikap. Materi pertama juga disampaikan pada sesi ini, meliputi penjabaran fenomena kekerasan seksual anak, definisi pendidikan seks, pentingnya pendidikan seks, tujuan dan manfaat pendidikan seks, serta tugas perkembangan anak usia 8-10 tahun.

Memasuki sesi kedua, peneliti menguraikan tentang perbedaan lawan jenis berdasarkan tugas-tugas sesuai jenis kelamin, pengetahuan tentang organ seks, fungsi, dan cara pemeliharaannya, persiapan menghadapi pubertas, dan perubahan sikap serta perilaku di masa pubertas. Sesi terakhir yakni sesi ketiga, peneliti akan mengupas hal-hal yang harus diperhatikan dalam menjada diri, mengidentifikasi orangorang dewasa yang dapat dipercaya untuk bercerita, dan pembekalan kemampuan menjaga diri. Pada sesi ini, selain materi, peneliti juga menayangkan video tentang kasus perkosaan anak dan empat bagian tubuh yang tidak boleh dipegang orang lain. Setelah materi di sessi ketiga disampaikan, peneliti membuka forum diskusi dengan subjek untuk menanyakan hal-hal yang kurang jelas berkenaan dengan materi yang disampaikan. Setelah itu, peneliti kembali meminta subjek untuk mengisi lembar kuesioner dan skala sikap (posttest), lalu dilanjutkan dengan penutupan.

\section{Analisis Data}

Analisa data diartikan sebagai upaya mengolah data menjadi informasi, sehingga karakteristik data dapat dipahami dan bermanfaat untuk menjawab masalah penelitian. Langkah dan prosedur analisa data meliputi tahap mengumpulkan data melalui instrumen pengumpulan data, tahap editing (memeriksa kejelasan dan kelengkapan pengisian instrumen), koding (identifikasi dan klarifikasi butir item dalam instrument), entri data dalam Microsoft excel, mendeskripsikan data melalui tabel atau diagram, dan terakhir yakni pengujian hipotesis, apakah hipotesis diterima atau ditolak.

Dalam penelitian ini data yang diperoleh merupakan data kuantitatif 
sehingga peneliti melakukan analisis untuk mengetahui apakah terdapat perbedaan yang signifikan terhadap pemberian psikoedukasi tentang pendidikan seks sebelum dan sesudah diberikan perlakuan. Analisis data menggunakan uji-t dengan metode paired sample t-test. Hasil penelitian bertujuan untuk melihat ada tidaknya peningkatan sikap pada subjek yang mengikuti psikoedukasi melalui perbandingan hasil dari skor prates dan pascates. Tahap ini digambarkan dalam gambar 2.

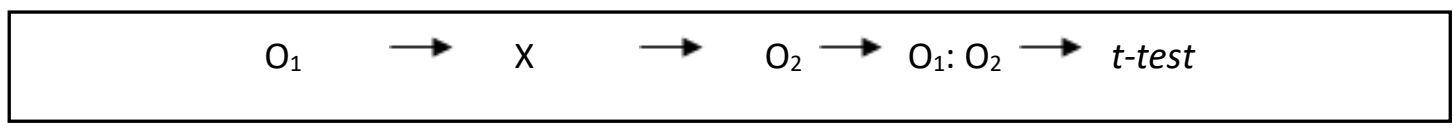

Gambar 2: tahapan perbandingan skor prates dan pascates dengan uji $t$

\author{
Keterangan: \\ $\mathrm{O}_{1} \quad$ : prates \\ $\mathrm{X} \quad$ : pemberian psikoedukasi \\ $\mathrm{O}_{2} \quad$ : Pascates \\ $\mathrm{O}_{1}: \mathrm{O}_{2}$ : membandingkan $\mathrm{O}_{1}$ dengan $\mathrm{O}_{2}$ \\ t-test : proses analisis data menggunakan rumus $t$-test
}

HASIL

Setelah penelitian dilakukan, diperoleh hasil yang akan dipaparkan dalam tabel-tabel berikut. Subjek penelitian berjumlah 19 orang dan hanya satu kelompok yang diberi perlakuan tanpa ada kelompok kontrol. Hal ini karena penelitian yang digunakan adalah pra eksperimen, sehingga tidak ada kelompok pembanding. Karakteristik subjek penelitian akan dijelaskan dalam Tabel 2.

Tabel 2. Deskripsi Subjek Penelitian

\begin{tabular}{lcc}
\hline \multicolumn{1}{c}{ Kategori } & Jumlah & Persentase \\
\hline Jenis Kelamin & & \\
Laki-laki & 1 & $5 \%$ \\
Perempuan & 18 & $95 \%$ \\
Usia & & \\
Dewasa Awal & 9 & $47 \%$ \\
Dewasa Menengah & 10 & $53 \%$ \\
\hline
\end{tabular}

Dari tabel 2, dapat diketahui subjek yang diberi perlakuan psikoedukasi tentang pendidikan seks sebanyak 19 orang yang terdiri dari 1 laki-laki (5\%) dan 18 perempuan (95\%). Dari 19 subjek tersebut, 9 orang (47\%) tergolong dalam usia dewasa awal dan 10 orang (53\%) termasuk usia dewasa menengah. Hasil skor rata-rata sikap orang tua dijabarkan oleh peneliti ke dalam dua kategori, yakni berdasarkan jenis kelamin dan kategori usia. Untuk lebih jelasnya, peneliti memaparkannya pada tabel 3. 
Tabel 3. Deskripsi Rata-rata Skor Sikap Orang Tua dalam Pemberian Pendidikan Seks pada Anak berdasarkan Jenis Kelamin dan Kategori Usia

\begin{tabular}{lcc}
\hline Kategori & Prates & Pascates \\
\hline Jenis kelamin & 92 & 89 \\
Laki-laki & 66 & 73.7 \\
Perempuan & & \\
Kategori usia & 178.7 & 199.6 \\
Dewasa awal & 137.2 & 150.5 \\
Dewasa menengah & & \\
\hline
\end{tabular}

Tabel 3 menunjukkan perbandingan skor sikap antara subjek laki-laki dan perempuan dalam memberikan pendidikan seks pada anak. Pada prates, rata-rata skor sikap orang tua laki-laki dalam pemberian pendidikan seks sebesar 92 dan pada orang tua perempuan sebesar 66. Sedangkan pada pascates rata-rata skor sikap orang tua lakilaki dalam pemberian pendidikan seks menjadi 89 dan orang tua perempuan meningkat menjadi 73,7. Meskipun pada subjek laki-laki mengalami penurunan ratarata skor, tetapi secara umum rata-rata skor orang tua dalam pemberian pendidikan seks meningkat pada pascates atau setelah pemberian psikoedukasi.

Perbandingan hasil antara subjek berusia dewasa awal dan dewasa menengah juga memperlihatkan peningkatan. Pada prates, rata-rata skor sikap orang tua usia dewasa awal 178,7 dan pada orang tua usia dewasa menengah sebesar 137,2. Sedangkan pada pascates rata-rata skor sikap orang tua usia dewasa awal sebesar 199,6 dan pada orang tua usia dewasa menengah sebesar 150,5 . Sehingga, secara umum rata-rata skor sikap orang tua usia dewasa awal dan dewasa menengah dalam pemberian pendidikan seks pada anak meningkat pada posttest atau setelah pemberian psikoedukasi.

Hasil skor rata-rata pemahaman orang tua dalam pemberian pendidikan seks pada anak dijabarkan oleh peneliti ke dalam dua kategori, yakni berdasarkan jenis kelamin dan kategori usia. Untuk lebih jelasnya, peneliti memaparkannya pada tabel 4.

Tabel 4. Deskripsi Rata-rata Skor Pemahaman Orang Tua dalam Pemberian Pendidikan Seks pada Anak berdasarkan Jenis Kelamin dan Kategori Usia

\begin{tabular}{ccc}
\hline Kategori & Prates & Pascates \\
\hline Jenis kelamin & 17 & 21 \\
Laki-laki & 17.4 & 20.6 \\
Perempuan & & \\
Kategori usia & 28.7 & 34.5 \\
Dewasa awal & 29.5 & 35.2 \\
Dewasa menengah & & \\
\hline
\end{tabular}


Tabel 4 menunjukkan perbandingan skor pemahaman antara subjek laki-laki dan perempuan dalam pemberian pendidikan seks pada anak. Pada prates, rata-rata skor pemahaman orang tua laki-laki dalam pemberian pendidikan seks sebesar 17 dan pada orang tua perempuan sebesar 17,4. Pada pascates rata-rata skor pemahaman orang tua laki-laki dalam pemberian pendidikan seks menjadi 21 dan orang tua perempuan meningkat menjadi 20,6. Secara umum rata-rata skor pemahaman orang tua dalam pemberian pendidikan seks meningkat pada pascates atau setelah pemberian psikoedukasi.

Perbandingan hasil antara subjek berusia dewasa awal dan dewasa menengah juga memperlihatkan adanya peningkatan. Pada prates rata-rata skor pemahaman orang tua usia dewasa awal 28,7 dan pada orang tua usia dewasa menengah sebesar 29,5. Sedangkan pada posttest, rata-rata skor pemahaman orang tua usia dewasa awal sebesar 34,5 dan pada orang tua usia dewasa menengah sebesar 35,2. Secara umum ratarata skor pemahaman orang tua usia dewasa awal dan dewasa menengah dalam pemberian pendidikan seks pada anak meningkat pada pascates atau setelah pemberian psikoedukasi.

Hasil penelitian membuktikan pemberian psikoedukasi tentang pendidikan seks berpengaruh terhadap sikap orang tua dalam memberikan pendidikan seks pada anak usia 8-10 tahun. Hal ini ditunjukkan oleh hasil uji paired sample $T$ test pada tabel 5 .

Tabel 5. Hasil Nilai Signifikansi Skala Sikap

\begin{tabular}{ccccc}
\hline & $\mathrm{N}$ & Correlation & $\mathrm{T}$ & $\mathrm{P}$ \\
\hline Jumlah & 19 & 0.610 & -2.932 & 0.009 \\
\hline
\end{tabular}

Tabel 5 menggambarkan total subjek (N) yang mengisi skala, mendapatkan psikoedukasi, dan mengisi prates dan pascates yaitu sebanyak 19 orang dengan nilai correlation sebesar 0.610 , nilai $\mathrm{T}_{\text {hitung }}$ sebesar -2.932, dan signifikansi (p) sebesar 0.009. Karena nilai $p<0.005$ maka $\mathrm{H} 1$ diterima, yakni dapat dikatakan terdapat pengaruh antara psikoedukasi dengan sikap orang tua terhadap pemberian pendidikan seks pada anak. Nilai correlation menunjukkan seberapa kuat pengaruh psikoedukasi terhadap sikap orang tua terhadap pemberian pendidikan seks pada anaknya. Nilai 0.610 yang mendekati angka 1 dan bersifat positif (+) menunjukkan psikoedukasi berpengaruh secara kuat terhadap sikap pemberian pendidikan seks orang tua pada anak usia 8-10 tahun. Hal ini digambarkan melalui gambar 3 . 


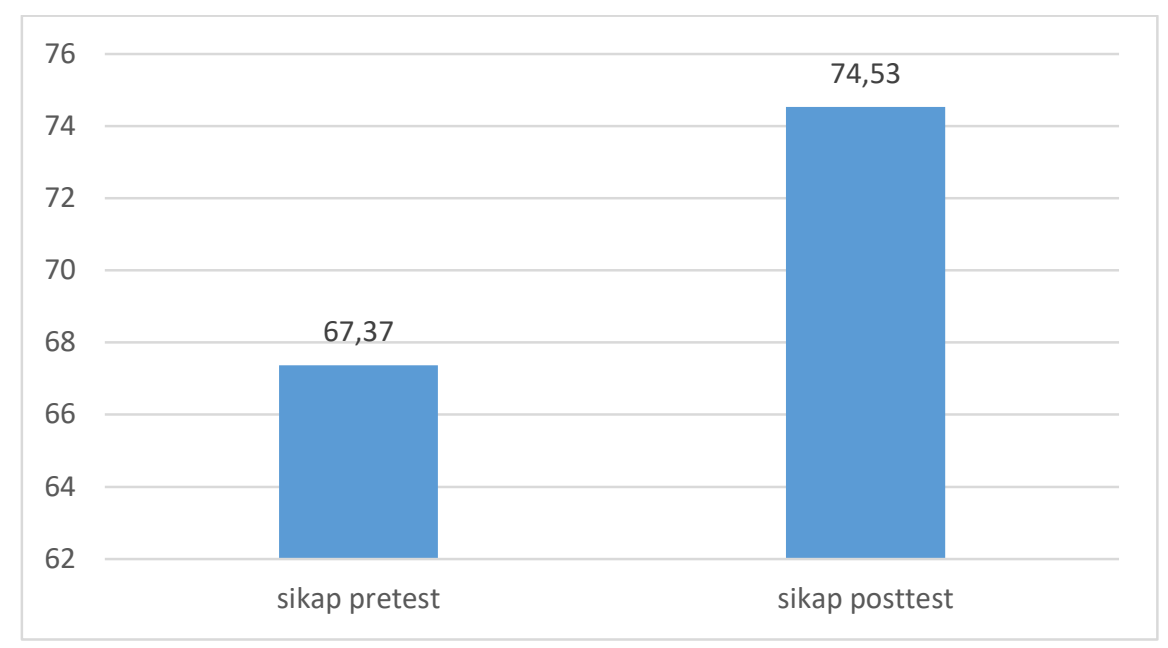

Gambar 3.

Rata-rata skor sikap orang tua sebelum dan sesudah pemberian psikoedukasi.

Gambar 3 menunjukkan rata-rata skor sikap orang tua terhadap pemberian pendidikan seks pada anaknya sebelum dan sesudah mendapatkan psikoedukasi. Sebelum mendapatkan psikoedukasi, ratarata skor sikap orang tua terhadap pemberian pendidikan seks sebesar 67.37. Sedangkan, setelah mendapatkan psikoedukasi, rata-rata skor sikap orang tua meningkat menjadi 74.53. Dengan demikian, pengetahuan subjek mengenai pendidikan seks dikatakan meningkat.

\section{Hasil Uji Pemahaman Orang Tua terhadap Pemberian Pendidikan Seks}

Selain menggunakan skala sikap, pretest dan posstest juga diukur melalui pemahaman orang tua terkait pemberian pendidikan seks pada anak. Uji pemahaman ini digunakan untuk mengetahui pemahaman awal orang tua tentang pemberian pendidikan seks dan peningkatan pemahaman orang tua tentang pemberian pendidikan seks pada anak setelah mendapatkan psikoedukasi. Uji pemahaman orang tua berdasarkan paired sample $t$ test akan dipaparkan pada tabel 6

Tabel 6. Hasil Nilai Signifikansi Uji Pemahaman

\begin{tabular}{ccccc}
\hline & $\mathrm{N}$ & Correlation & $\mathrm{t}$ & $\mathrm{P}$ \\
\hline Jumlah & 19 & 0.126 & -6.942 & 0.000 \\
\hline
\end{tabular}

Tabel 6 menunjukkan 19 subjek yang mendapatkan psikoedukasi, diperoleh jumlah nilai correlation sebesar 0.126 , nilai t sebesar -6.942 dan nilai signifikansi (p) sebesar 0.000 . Karena nilai $p<0.005$, maka
H1 diterima, yakni dapat dikatakan terdapat pengaruh antara psikoedukasi dengan peningkatan pemahaman orang tua terhadap pemberian pendidikan seks pada anak. 


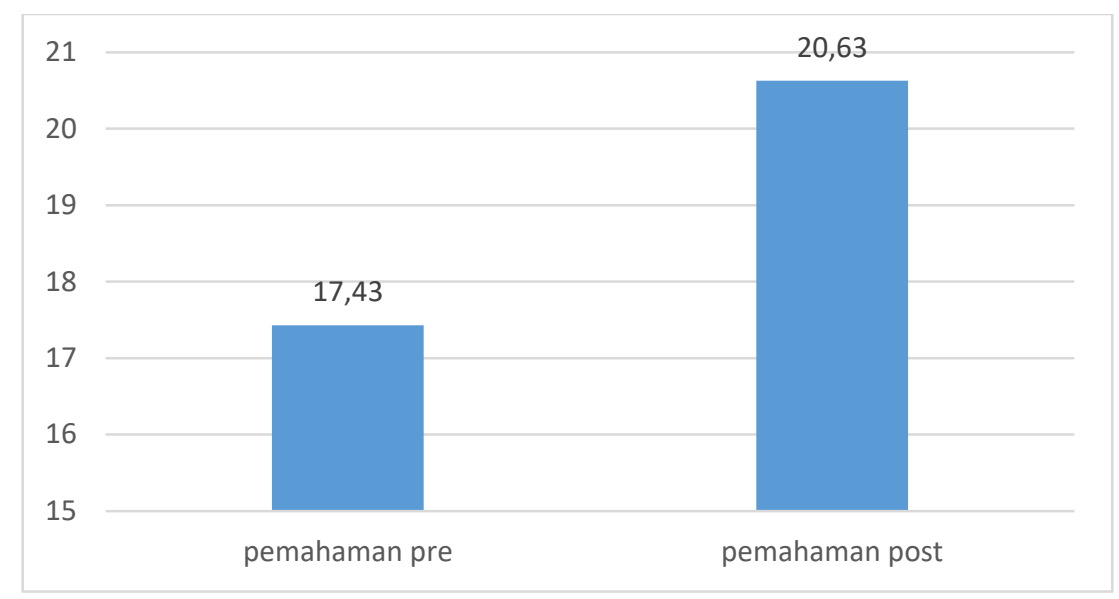

Gambar 4 .

Rata-rata skor pemahaman orang tua sebelum dan sesudah pemberian psikoedukasi.

Gambar 4 menunjukkan skor ratarata pemahaman orang tua terhadap pemberian pendidikan seks pada anak sebelum dan sesudah mendapatkan psikoedukasi. Sebelum mendapatkan psikoedukasi, skor rata-rata pemahaman orang tua terhadap pemberian pendidikan seks sebesar 17.43. Setelah mendapatkan psikoedukasi, skor rata-rata pemahaman orang tua meningkat menjadi 20.63. Dengan demikian, pengetahuan subjek mengenai pendidikan seks dikatakan meningkat.

\section{Pembahasan}

Psikoedukasi diberikan pada orang tua sebagai upaya untuk meningkatkan sikap orang tua tentang pendidikan seks. Dengan mengetahui pentingnya pendidikan seks, orang tua diharapkan mampu memberikan pendidikan seks pada anak tanpa perlu merasa tabu. Hal ini karena orang tua adalah unsur paling penting dalam membicarakan perkembangan dan pendidikan seks pada anak sebelum pihakpihak lain.

Berdasarkan hasil penelitian yang dilakukan, diketahui bahwa terdapat peningkatan sikap orang tua dalam memberikan pendidikan seks untuk anaknya. Hasil tersebut dibuktikan dengan uji paired sample t test terhadap skor prates dan pascates yang mengalami peningkatan. Selain mengukur skor pretest dan posttest, peneliti juga melihat pemahaman subjek akan pentingnya pendidikan seks. Hasilnya juga memperlihatkan adanya peningkatan pemahaman sebelum dan sesudah memperoleh psikoedukasi tentang pendidikan seks.

Dalam penelitian ini, peneliti juga melakukan analisa data penelitian berdasarkan jenis kelamin dan klasifikasi usia. Orang tua siswa yang masuk kategori usia dewasa awal (9 orang) memperoleh rata-rata nilai skala sikap, baik sebelum dan sesudah pemberian psikoedukasi lebih tinggi dibandingkan orang tua yang termasuk dalam usia dewasa menengah. Menurut Santrock, usia dewasa awal berada pada rentang 20- 40 tahun. Sembilan dari 19 subjek penelitian berada pada masa usia dewasa awal ini, yakni 30-40 tahun. Dewasa awal merupakan suatu masa penyesuaian terhadap pola-pola kehidupan yang baru dan harapan-harapan sosial yang baru (Hurlock, 1978).

Terkait, dengan pola kehidupan yang baru, orang-orang usia dewasa awal merupakan generasi yang masuk dalam kategori digital native, yakni seluruh 
hidupnya bersentuhan langsung dengan teknologi. Orang tua yang menggunakan gadget dan mengakses beragam informasi dari berbagai sumber di internet, termasuk pendidikan seks untuk anak, merupakan salah satu contoh orang dewasa awal yang bersentuhan dengan teknologi dalam kehidupannya. Hal ini dibuktikan dari soal pemahaman yang diajukan pada orang tua. Orang tua mengaku mengetahui pentingnya pendidikan seks salah satunya melalui internet. Sementara, orang tua usia dewasa menengah masuk dalam kategori digital immigrant yakni masyarakat peralihan yang separuh usianya hidup dalam perkembangan teknologi dan mengikutinya. Hal ini juga tampak dari jawaban pada soal pemahaman yang menyatakan bahwa beberapa di antara orang tua mengetahui apa itu pendidikan seks dari internet (Haiti, 2016).

Hal tersebut berhubungan dengan faktor-faktor pembentuk sikap menurut Azwar (1988), yakni pengalaman pribadi, pengaruh orang lain yang dianggap penting, pengaruh kebudayaan, media massa, lembaga pendidikan dan agama, serta pengaruh emosional. Media massa dan teknologi mempunyai pengaruh dalam perubahan sikap seseorang. Adanya informasi baru mengenai sesuatu hal memberikan landasan kognitif bagi terbentuknya sikap. Pesan-pesan sugestif yang dibawa oleh informasi tersebut akan memberi dasar afektif dalam menilai sesuatu hal sehingga terbentuklah arah sikap tertentu.

Orang tua usia dewasa awal dan dewasa menengah memiliki pandangan yang berbeda terkait pendidikan seks (Putri, 2012). Orang tua generasi dahulu atau yang masuk dalam kategori dewasa menengah, memandang pendidikan seks sebagai hal yang lebih tabu dibandingkan orang tua usia dewasa awal. Pertentangan terhadap pendidikan seks lebih banyak muncul dari pihak generasi tua yang berpendapat bahwa pendidikan seks tidak sesuai dengan adat ketimuran (Dawi, dalam Putri 2012). Berdasarkan hasil penelitian, jumlah orang tua yang memberikan pendidikan seks untuk anak lebih sedikit dibandingkan orang tua yang tidak memberikan pendidikan seks pada anak. Orang tua yang tidak memberikan pendidikan seks untuk anak menyatakan bahwa anak-anak belum waktunya atau masih terlalu kecil untuk diberikan pendidikan seks. Menurut Surbakti (Putri, 2012), terdapat tipikal orang tua yang memaknai terminologi seks sebagai senggama, sehingga orang tua biasanya mengaitkan seks dengan ranjang.

Dilihat dari jenis kelamin orang tua, dalam hal pendidikan pada anak, orang tua perempuan atau ibu, lebih banyak mengambil peran dibandingkan dengan pihak lain (Roqib, 2008). Ibu lebih banyak bertanggung jawab dalam pendidikan anak selama awal masa hidupnya dibandingkan ayah, sehingga penentuan peran seks lebih dilakukan ibu daripada ayah (Hurlock, 1978). Ibu yang memiliki sikap positif dalam pemberian informasi tentang seksualitas memiliki peluang enam kali lebih besar untuk memberikan informas tentang seksualitas (Ratih, 2016).

penelitian Ratih (2016) menyatakan ibu sangat berperan dalam penerapan pendidikan seksual pada anak. Ibu memberikan informasi, arahan, dan pemahaman yang benar tentang seksual pada anak. Meskipun begitu, ibu masih sungkan berbicara tenrang hal yang berkaitan dengan seksual kepada anakanaknya karena masih menganggap tabu dan belum perlu diberikan sejak dini. Hal ini sesuai dengan hasil yang diperoleh peneliti bahwa orang tua, utamanya ibu, banyak yang masih enggan memberikan pendidikan seks pada anak kendati ibu memiliki pengetahuan tentang itu. Hasil penelitian yang dilakukan oleh Nambambi dan Mufune (2011) menyatakan sebagian besar orang tua memulai diskusi terbatas tentang 
seksualitas. Ibu mulai membahas isu-isu seksualitas dengan anak perempuan ketika anak mulai menstruasi. Sedangkan, ibu memberikan pendidikan seks pada anak laki-laki beberapa tahun setelah anak perempuan.

Hasil penelitian Dyson (2010) menyatakan pengalaman pendidikan seks yang diterima orang tua di masa muda relevan dengan sikap orang tua tentang pendidikan seksual yang diberikan pada anaknya. Kaum ibu masa kini berusaha membicarakan tentang seks dengan anaknya secara perlahan dan dalam suasana yang santai. Beberapa ibu lain mengikuti cara orang tuanya dahulu saat berbicara, karena menganggap hal itu lebih positif.

Psikoedukasi dalam penelitian ini berpengaruh positif dalam meningkatkan sikap orang tua terhadap pemberian pendidikan seks pada anaknya. Hal ini dikarenakan jika subjek memiliki pengetahuan yang tinggi tentang pendidikan seks, maka sikap subjek terhadap pendidikan seks akan menjadi positif sehingga subjek akan memberikan pendidikan seks pada anaknya. Sebaliknya, jika subjek kurang memiliki pengetahuan mengenai pemberian pendidikan seks, maka sikap subjek terhadap psikoedukasi seks untuk anak akan negatif sehingga subjek cenderung untuk tidak memberikan pendidikan seks untuk anaknya (Anugraheni, 2012).

Psikoedukasi

merupakan pengembangan dan pemberian informasi dalam bentuk pendidikan mengenai informasi yang berkaitan dengan psikologi populer atau sederhana atau informasi lain yang mempengaruhi kesejahteraan psikososial masyarakat. Pemberian informasi ini dapat meningkatkan kemampuan kognitif karena mengandung unsur pengajaran tentang materi untuk meningkatkan dukungan bagi subjek yang dikenainya (Supratiknya, 2011).
Dalam penelitian ini, untuk meningkatkan sikap orang tua terhadap pemberian pendidikan seks pada anak, peneliti memberikan psikoedukasi yang di dalamnya terdapat beberapa muatan yang berpengaruh untuk meningkatkan sikap orang tua. Peneliti memaparkan fakta tentang banyaknya kasus kekerasan seksual pada anak yang beberapa tahun terakhir banyak terjadi. Tujuannya untuk membuka wawasan pada orang tua tentang fenomena yang terjadi jika anak tak memiliki bekal tentang diri dan orang-orang di lingkungan sekitarnya. Peneliti juga menjelaskan sekilas tentang perkembangan anak usia 8-10 tahun, baik perkembangan fisik, kognitif, emosi, maupun sosial.

Peneliti menguraikan tentang pendidikan seks dan mengapa orang tua penting untuk memberikannya pada anak. Dalam hal ini, peneliti mengaitkannya dengan fenomena dan perkembangan anak yang telah dipaparkan sebelumnya. Sebagai penguat, peneliti memaparkan cara-cara memberikan pendidikan seks pada anak melalui video animasi dan mengajukan pertanyaan tentang mitos dan fakta terkait perkembangan seksual anak. Cara ini untuk membangun pemahaman mana hal yang benar dan hanya persepsi dalam masyarakat terkait perkembangan anak dan bagaimana orang tua harus menyikapinya. Sehingga, materi yang diberikan fasilitator pada psikoedukasi ini menyumbang penting terhadap peningkatan sikap orang tua dalam peningkatan sikap dan pemahaman orang tua. Al-Yahya (2014) dalam penelitiannya menyatakan, wawasan dan pengetahuan yang diberikan dalam psikoedukasi memberikan efek pada nilai perubahan yang signifikan dan nilai yang tinggi setelah pelaksanaan intervensi.

Dalam melakukan penelitian, ada beberapa hal yang menjadi keterbatasan peneliti. Pertama, subjek penelitian. Jumlah yang akan dijadikan subjek penelitian adalah orang tua dari murid kelas III di SD Negeri M 
Malang yakni sebanyak 39 orang. Akan tetapi, pada waktu pelaksanaan psikoedukasi, jumlah subjek yang hadir dan mengikuti seluruh rangkaian kegiatan mulai dari prates, psikoedukasi, dan pascates hanya 19 orang.

Kedua, waktu yang digunakan peneliti untuk melakukan psikoedukasi adalah di akhir pekan. Ada beberapa orang tua yang tidak bisa meninggalkan pekerjaan sehingga tidak dapat hadir atau hadir tapi tidak dapat mengikuti rangkaian kegiatan secara penuh, sehingga tidak termasuk dalam hitungan subjek.

Ketiga, kendala yang dinilai peneliti sebagai kendala terbesar yakni mengenai persepsi orang tua akan pendidikan seks. Meski 16 dari 19 orang tua mengaku pendidikan seks penting diberikan pada anak, namun kebanyakan orang tua tidak memberikan pendidikan seks pada anaknya karena menganggap anak-anak masih terlalu kecil untuk mengerti tentang seks. Pendidikan seksual seringkali dipandang sebatas fenomena biologis dan cenderung menggambarkan hal yang tabu dan berbahaya yang dikontrol melalui moral dan agama (Joyo, 2016).

\section{Simpulan dan Saran}

\section{Simpulan}

Berdasarkan analisis data, terdapat perbedaan skor prates dan pascates sikap dan pemahaman orang tua sebelum dan sesudah diberi psikoedukasi. Hasil rata-rata skor subjek meningkat setelah diberi psikoedukasi. Hal ini membuktikan bahwa pemberian psikoedukasi dapat meningkatkan sikap orang tua dalam pemberian pendidikan seks pada anak usia 8-10 tahun.
Implikasi dari penelitian ini, terdapat peningkatan sikap orang tua dalam pemberian pendidikan seks pada anak setelah mendapatkan psikoedukasi dari peneliti. Selanjutnya, peneliti berharap kepada orang tua agar lebih intens dalam memberikan pendidikan seks pada anak tanpa merasa malu dan tabu. Hal ini dapat dilakukan dengan menggunakan bahasa yang jelas dan sederhana sehingga mudah dimengerti anak. Orang tua juga diharapkan menjawab setiap pertanyaan anak berkaitan dengan seksualitas, bukan mendiamkan dan mengalihkannya pada hal lain. Selain itu, untuk mengontrol kegiatan anak di sekolah atau di luar rumah, orang tua diharapkan dapat menjali komunikasi yang baik dengan anak dengan cara mengajaknya berbagi cerita tentang hal-hal yang dialaminya. Hal ini untuk menumbuhkan rasa percaya dan keterbukaan anak pada orang tua.

\section{Saran}

Untuk penelitian selanjutnya diharapkan dapat melakukan perbaikan dalam berbagai hal. Misalnya, pemberian psikoedukasi dilakukan lebih dari satu kali pertemuan dengan materi yang lebih terperinci, sehingga efektivitas psikoedukasi akan meningkat. Materi yang dibuat juga bisa berdasarkan identifikasi masalah yang dialami orang tua, sehingga materi yang diberikan akan lebih terfokus. Peneliti selanjutnya juga dapat membuat buku saku yang menarik untuk diberikan pada orang tua sebagai panduan dalam memberikan pendidikan seks pada anaknya. Untuk follow up, peneliti diharapkan juga memberikan pascates beberapa bulan setelah pemberian psikoedukasi untuk mengontrol sejauh mana intervensi ini berpengaruh dan dipraktikkan oleh orang tua dalam pemberian pendidikan seks pada anak. 


\section{Daftar Pustaka}

Al-Yahya, Nora M. (2014). Effects of psychoeducation intervension in improving insight and medication compliance of schizophrenic clients, Riyadh, Saudi Arabia. Journal of Medical Sciences, 11(3), 289-300.

Anugraheni, Efrida, et al. (2012). Hubungan pengetahuan dan sikap orang tua tentang pendidikan seks dengan tindakan orang tua dalam pemberian pendidikan seks pada remaja (studi di Kecamatan Sumbersari Kabupaten Jember). Artikel Ilmiah Hasil Penelitian Mahasiswa. Universitas Negeri Jember.

Asra, Yulita Kurniawaty. (2013). Efektivitas psikoedukasi pada orangtua dalam meningkatkan pengetahuan seksual remaja retardasi mental ringan. Jurnal Psikologi 9(1). Riau: UIN Sultan Syarif Kasim.

Azwar, Saifuddin. (1988). Sikap manusia: Teori dan pengukurannya. Yogyakarta: Penerbit Liberty.

Dyson, Sue. (2010). Parents and sex education: parents' attitudes to sexual health education in WA schools. Australian Research Centre in Sex, Health, and Society. La Trobe University, Melbourne, Australia.

Elisa, Syafrida \& Wrastari, Aryani Tri. (2013). Sikap guru terhadap pendidikan inklusi ditinjau dari faktor pembentukan sikap. Jurnal Psikologi Perkembangan dan Pendidikan, 2(01).
Erlinda. (2015). Upaya peningkatan anak dari bahaya kekerasan, pelecehan, dan eksploitasi. Diperoleh 30 Oktober 2016 pukul 23.50 dari https://web.kominfo.go.id/sites/def ault/files/paparan-kementerian2014-nov-bandung-erlinda-REVfix.pdf

Erni. (2013). Pendidikan seks pada remaja. Lurnal Health Quality 3(2), 69-140.

Gunarsa, Singgih D. (2013). Psikologi untuk keluarga. Jakarta: Penerbit BPK Gunung Mulia.

Haiti, Badrodin. (2016, ). Orasi di wisuda UMM, kapolri: Manfaatkan era digital native. Diperoleh 4 November 2016 pukul 23.42 dari http://www.umm.ac.id/id/berita/o rasi-di-wisuda-umm-kapolrimanfaatkan-era-digital-native.html

Hamdi, Imam. (2015, 31 Juli). Menyedihkan, anak-anak menjadi pelaku pelecehan seksual di depok. Diperoleh 27 Oktober 2016 pukul 00.15 dari https://m.tempo.co/read/news/20 $15 / 07 / 31$ 1064687975/menyedihkan-anakanak-menjadi-pelaku-pelecehanseksual-di-depok

Herjanti. (2015). Pola asuh orang tua tentang pendidikan seks anak usia dini. Jurnal Ilmu Kebidanan Indonesia, $5(2)$.

Hidayati, Farida, dkk. (2011). Peran ayah dalam pengasuhan anak. Jurnal Psikologi Undip, 9(2). 
Hurlock, Elizabeth B. (1978). Perkembangan anak jilid 2. Jakarta: Erlangga.

Hurlock, Elizabeth B. (1980). Psikologi perkembangan: Suatu pendekatan sepanjang rentang kehidupan. Jakarta: Penerbit Erlangga.

Indonesia Darurat Kekerasan pada Anak. (2014). Diperoleh 14 November 2016 pukul 22.40 dari http://nasional.kompas.com/read/ 2014/05/07/indonesia.darurat.kek erasan.pada.anak

Joyo, Troi Suryo Baskoro. (2016). Gambaran persepsi orang tua terhadap pendidikan seks pada anak usia sekolah di SDN Banjarsari Kecamatan Windusari Kabupaten Magelang. Skripsi. Universitas Diponegoro, Semarang.

Latipun. (2002). Psikologi eksperimen. Malang: Universitas Muhammadiyah Malang Press.

Nambambi, Ndishishi M \& Pempelani Mufune. (2011). What is talked about when parents discuss sex with children: family based sex education in Windhoek, Namibia. African Journal of Reproductive Health December, 15(4), 120.

Ningsih, Rika Kurnia. (2016). Terdakwa pemerkosa dan pembunuh yuyun dijatuhi hukuman mati. Diperoleh 20 November 2016 pukul 20.45 dari http://www.bbc.com/indonesia /berita indonesia/2016/09/16092 9 indonesia yuyun vonis terdakwa

Purba, David Oliver. (2016, 13 Juni). Bocah kelas 5 sd yang dicabuli pamannya di tanjung priok alami trauma. Diperoleh 26 Oktober 2016 pukul 23.50, dari http://megapolitan.kompas.com/re ad

/2016/06/13/20553791/bocah.kel as.5.sd.yang.dicabuli.pamannya.di.ta njung.priok.alami.trauma
Puspasari, Kiemas Ratih. (2016). Hubungan bimbingan orang tua dalam belajar dengan prestasi belajar siswa kelas IV SD Negeri 2 Rawa Laut Kota Bandar Lampung tahun ajaran 2015/2016. Skripsi. Universitas Lampung.

Putranto, Kasandra. (2016, November). Langkah psikologi dan hukum mereduksi tindakan kekerasan seksual pada anak. Makalah yang disampaikan dalam Seminar Nasional Pencegahan Sex Abuse.

Putri, Imanda Kartika. (2012). Faktor-faktor yang berhubungan dengan perilaku pemberian pendidikan seks untuk anak oleh orang tua siswa Madrasah Ibtidaiyah Hayatul Islamiyah Depok tahun 2012. Universitas Indonesia Depok.

Rahmi, Amelia. (2013). Pengenalan literasi media pada anak usia sekolah dasar. Lurnal Studi Gender dan Anak. Semarang: IAIN Walisongo.

Ramadhan, Bilal. (2014). Polisi: Tiga siswa JIS jadi korban pelecehan seksual. Diperoleh 16 November 2016 pukul 16.30 dari http://www.republika.co.id/berita/ nasional/hukum/14/07/15/n8qutjpolisi-tiga-siswa-jis-jadi-korbanpelecehan-seksual

Ratih, Yulia. (2016). Analisis faktor yang berhubungan dengan praktik pendidikan seks oleh ibu yang memiliki anak autis usia remaja (studi di SLB Negeri Kota Semarang). Lurnal Kesehatan Masyarakat (eLournal), 4(2).

Raudhoh, Siti. (2013). Psikoedukasi: intervensi, rehabilitasi dan Prevensi. Universitas Padjajaran Bandung.

Rifani, Taat. (2014). Konsep pendidikan seks dalam perspektif fikih. Skripsi. Institut Agama Islam Negeri Walisongo, Semarang. 
Roqib, Moh. (2008). Pendidikan seks pada anak usia dini. Jurnal Pemikiran Alternatif Pendidikan, 13(2).

Santrock, John W. (2012). Life-span development: perkembangan hidup manusia. Jakarta: Penerbit Erlangga.

Sarwono, S. W. (2010). Psikologi remaja edisi revisi. Jakarta: Rajawali Pers.

Sarwono, Sarlito W. \& Meinarno, Eko A. (2012). Psikologi sosial. Jakarta: Salemba Humanika.

Setyawan, Davit. (2015, 14 Juni). KPAI: Pelaku kekerasan terhadap anak tiap tahun meningkat. Diperoleh 30 Oktober 2016 pukul 22.20 dari http://www.kpai.go.id/berita/kpaipelaku-kekerasan-terhadap-anaktiap-tahun-meningkat/Siswi 13 tahun digilir 8 siswa, 5 SMP dan 3 SD. (2016). Diperoleh 26 Oktober 2016 pukul 00.20 dari http://poskotanews.com/2016 /05/12/siswi-13-tahun-digilir-8siswa-5-smp-dan-3-sd/
Sugiyono. (2012). Metode penelitian kuantitatif, kualitatif dan r\&b. Bandung: Alfabeta.

Supratiknya, A. (2011). Merancang program dan modul psikoedukasi. Edisi Revisi. Yogyakarta: Universitas Sanata Dharma.

Suryabrata, S. (1998). Psikologi Pendidikan. Jakarta: PT Raja Grafindo Persada.

Walgito, Bimo. (1991). Psikologi sosial: suatu pengantar. Yogyakarta: Andi Offset.

Walsh, Joseph. (2010). Psychoeducation in mental health. Chicago: Lyceum Books, Inc.

Widjanarko, A. (1994). Sex education dalam pandangan islam. Jakarta: Palinggam. 
Isnatul Chasanah 